\title{
Faktor Internal dan Eksternal yang Menentukan Non Performing Financing (NPF) pada Pembiayaan Mudharabah
}

\author{
Rahdya Iasyah Nindea Tami* \\ Prodi Ilmu Ekonomi, Fakultas Ekonomi dan Bisnis, Universitas Islam \\ Bandung, Indonesia. \\ *rahdyadea@gmail.com
}

\begin{abstract}
In recent years, the world of Islamic banking in Indonesia has shown very rapid development, both in terms of the number of new office openings, types of bank businesses and the volume of bank activities they do. Al Salaam SRBs are BPRS that are superior compared to other SRBs in the city of Bandung. However, the level of BPRS Al Salaam's problematic financing (NPF) was the highest among other BPRS. The problematic financing that occurred at the Al Salaam SRB was due to several factors and processes that did not occur quickly, where these factors could be sourced from bank management aspects as well as customer aspects. This study aims to identify the Internal and External Factors that determine Non-Performing Financing (NPF) in mudharabah financing at Al Salaam Bandung Branch. This type of research used in this research is quantitative descriptive research with survey methods. The survey method was carried out by interviewing and distributing questionnaires to 10 respondents namely 5 bank management parties and 5 customers. Sampling is done by simple calculations using purposive sampling technique. Data sources used in this study consisted of two types, namely secondary data and primary data. The analytical method used is the Likert scale analysis method. Test requirements analysis using validity and reliability tests are assisted using the SPSS program. The results showed that aspects of bank management from the perspective of bank employees and customers are at sufficient intervals to determine the occurrence of problematic financing or NPF while customer aspects from the perspective of bank employees and customers themselves are at intervals determining the occurrence of problematic financing or NPF.
\end{abstract}

Keywords: Problem Funding, Bank Management Aspects, Customer Aspects, Mudharabah Financing.

Abstrak. Pada tahun-tahun terakhir ini dunia perbankan Syariah di Indonesia menunjukkan perkembangan yang sangat pesat, baik dilihat dari jumlah pembukaan kantor baru, jenis usaha bank dan volume kegiatan bank yang dilakukannya. BPRS Al Salaam termasuk BPRS yang lebih unggul dibandingkan dengan BPRS lainnya di kota Bandung. Namun demikian, tingkat pembiayaan bermasalah (NPF) BPRS Al Salaam pun paling tinggi diantara BPRS lainnya. Pembiayaan bermasalah yang terjadi di BPRS Al Salaam disebabkan beberapa faktor dan proses yang tidak terjadi secara cepat, dimana faktor tersebut dapat bersumber dari aspek manajemen bank maupun aspek nasabah. Penelitian ini bertujuan untuk mengidentifikasi Faktor Internal dan Eksternal yang menentukan Non Performing Financing (NPF) pada pembiayaan mudharabah di BPRS Al Salaam Cabang Bandung.Jenis penelitian yang digunakan dalam penelitian ini adalah penelitian deskriptif kuantitatif dengan metode survei. Metode survei dilakukan dengan wawancara dan menyebarkan kuisioner kepada 10 responden yaitu pihak manajemen bank sebanyak 5 orang dan pihak nasabah sebanyak 5 orang. Pengambilan sampel dilakukan dengan perhitungan sederhana menggunakan teknik purposive sampling. Sumber data yang digunakan dalam penelitian ini terdiri dari dua jenis yaitu data sekunder dan data primer. Metode analisis yang digunakan adalah metode analisis skala likert. Uji persyaratan analisis menggunakan uji validitas dan reabilitas dibantu menggunakan program SPSS.Hasil penelitian menunjukkan bahwa aspek manajemen bank menurut perspektif karyawan bank maupun nasabah berada pada interval cukup menentukan terjadinya pembiayaan bermasalah atau NPF sedangkan Aspek nasabah menurut perspektif karyawan bank maupun nasabah itu sendiri berada pada interval menentukan terjadinya pembiayaan bermasalah atau NPF.

Kata Kunci: Pembiayaan Bermasalah, Aspek Manajemen Bank, Aspek Nasabah, Pembiayaan Mudharabah 


\section{A. Pendahuluan}

Dinamika perkembangan industri bank syariah saat ini sudah memasuki dekade ketiga, dimana perkembangan tersebut ditandai dengan tingkat persaingan antar bank dalam mempertahankan performa atau tingkat kesehatannya. Performa bank syariah sebagai lembaga keuangan dapat dilihat dari sejauh mana bank tersebut mampu menyalurkan pembiayaan kepada sektor riil secara optimal dan baik. (Tiarani, 2018).

Dalam hal ini, BPRS Al Salaam Cabang Bandung merupakan BPRS dengan jumlah penyaluran pembiayaan dan asset terbesar di kota Bandung urutan kelima (Putra, 2018). Berikut ini gambaran kinerja keuangan BPRS yang ada di Kota Bandung periode akhir 2018:

\section{Tabel 1.1}

Kinerja Keuangan BPRS di Kota Bandung Tahun 2018

\begin{tabular}{|l|c|c|c|c|}
\hline \multicolumn{1}{|c|}{ Nama Bank } & CAR & R0A & FDR & NPF \\
\hline BPRS Al Salaam & $12.13 \%$ & $8.78 \%$ & $98.99 \%$ & $4.17 \%$ \\
\hline BPRS HIK Parahyangan & $11.36 \%$ & $7.77 \%$ & $92.36 \%$ & $3.25 \%$ \\
\hline BPRS Mitra Harmoni & $11.11 \%$ & $7.36 \%$ & $88.76 \%$ & $3.34 \%$ \\
\hline BPRS Amanah Rabaniyah & $8.67 \%$ & $7.21 \%$ & $88.66 \%$ & $3.56 \%$ \\
\hline BPRS Baiturridho & $8.36 \%$ & $6.89 \%$ & $85.68 \%$ & $2.28 \%$ \\
\hline
\end{tabular} Sumber: www. ojk.go.id Yang sudah diolah penulis, 2019.

Berdasarkan tabel di atas, terlihat bahwa kinerja keuangan dari sisi modal (CAR), rentabilitas (ROA) dan kemampuan menyalurkan pembiayaan atau FDR (aktiva produktif) BPRS Al Salaam lebih unggul dibandingkan dengan BPRS lainnya. Namun demikian, menurut hasil wawancara dengan Bapak Rachmat selaku Brand Manager BPRS Al Salaam Cabang Bandung tingkat pembiayaan bermasalah (NPF) BPRS Al Salaam pun paling tinggi diantara BPRS lainnya. Besar NPF di BPRS Al Salaam tidak lepas dari besarnya dana pembiayaan yang disalurkan. Dalam hal ini, kinerja Bank BPRS Al Salaam Cabang Bandung rupanya tak sejalan dengan perusahaan induk. Jika BPRS Al Salaam Pusat yang berkedudukan di Cinere - Depok mencetak pertumbuhan laba yang besar di semeter I - 2018, BPRS Al Salaam Cabang Bandung mencatat penurunan laba drastis untuk periode yang sama.

NPF atau dikenal dengan pembiayaan bermasalah yaitu terjadinya suatu kasus dimana pihak nasabah mengingkari janjinya membayar margin dan atau pokok pembiayaan yang telah jatuh tempo, sehingga terjadi keterlambatan pembayaran atau sama sekali tidak ada pembayaran. Hal ini akan menyebabkan mutu pembiayaan dalam akad mudharabah tersebut mengalami kemerosotan (Sutojo, 2007: 2). Dalam kasus pembiayaan bermasalah secara teoritis penyebabnya terjadi karena terdapat kemungkinan bank syariah terpaksa melakukan tindakan hukum, atau menderita kerugian dalam jumlah yang jauh lebih besar dari jumlah yang diperkirakan (pada saat akad atau pemberian dana pembiayaan) dapat ditolerir. Oleh karena itu bank yang bersangkutan harus mengalokasikan perhatian, tenaga, dana, waktu dan usaha secukupnya guna menyelesaikan kasus itu (Sutojo: 13). Kasus pembiayaan bermasalah terjadinya tidak secara tiba-tiba, karena pada umumnya sebelum mengalami pembiayaan bermasalah terlebih dahulu akan mengalami tahap bermasalah.

Terkait hal di atas, maka dapat dikatakan bahwa pembiayaan bermasalah yang terjadi di BPRS Al Salaam disebabkan beberapa faktor dan proses yang tidak terjadi secara cepat, dimana faktor tersebut dapat bersumber dari pihak nasabah atau dari manajemen bank itu sendiri. Merujuk pada observasi yang penulis lakukan pada bulan Januari 2019, yaitu penulis melakukan wawancara mengenai pembiayaan dengan Bapak Ridwan Nasruddin selaku Account Officer dan Bapak Tujar selaku Sales Officer BPRS Al Salaam Cabang Kota Bandung, bahwa salah satu produk pembiayaan yang paling sering digunakan dan diminati nasabah BPRS Al Salaam Cabang Kota Bandung adalah produk pembiayaan dengan akad murabahah, bahkan banyaknya jumlah pembiayaan murabahah tersebut mencapai $80 \%$.

Selain pembiayaan murabahah, BPRS Al Salaam sendiri memiliki produk pembiayaan 
dengan skim bagi hasil atau Mudharabah. Akan tetapi, penyaluran pembiayaan tersebut tidak selamanya berjalan dengan baik dan lancar terutama dengan akad Mudharabah yang memiliki tingkat risiko lebih besar serta plafon pembiayaan yang rata-rata di atas Rp. 50 juta. Dalam hal ini, pembiayaan bermasalah di BPRS Al Salaam direpresentasikan dengan rasio NPF. Berikut ini merupakan gambaran dari rasio NPF dan pembiayaan yang disalurkan baik dengan akad Mudharabah dan Murabahah di BPRS Al Salaam Cabang selama tiga tahun terakhir:

\begin{tabular}{|c|c|c|c|c|c|}
\hline \multicolumn{6}{|c|}{$\begin{array}{c}\text { Tabel } 1.2 \\
\text { Persentase NPF dan Alokasi Pembiayaan Mudharabah dan Murabahah } \\
\text { diBPRS Al Salaam Periode 2016-2018 }\end{array}$} \\
\hline $\begin{array}{l}\text { Pembiayaan } \\
\text { Uudharabah }\end{array}$ & $\begin{array}{l}\text { Pembiayaan } \\
\text { Mudharabah } \\
\text { Bermasalah }\end{array}$ & $\mathrm{NPF}$ & $\begin{array}{l}\text { Pembiayaan } \\
\text { Murabahah }\end{array}$ & $\begin{array}{l}\text { Pembiayaan } \\
\text { Murabahah } \\
\text { Bermasalah } \\
\end{array}$ & $\mathrm{NP}$ \\
\hline .250.878.144,- & Rp. 23.627.312,83 & $9.41 \%$ & Rp. 1.674.974.468 & Rp. 92.291.093 & $5.51^{\prime}$ \\
\hline $321.988 .565,-$ & Rp. 25.630.542,61 & $7.96 \%$ & Rp. 1.823.285.841 & Rp. 83.688.820 & 4.59 \\
\hline $350.877 .655,-$ & Rp. 29.817.264,50 & $8.49 \%$ & Rp. 1.875.472.819 & Rp. 79.144.952 & 4.22 \\
\hline
\end{tabular}

Berdasarkan tabel di atas, terlihat bahwa persetase NPF di BPRS Al Salaam Cabang untuk pembiayaan dengan skim bagi hasil atau akad mudharabah tergolong cukup besar dan berada pada kategori macet. Namun demikian, NPF secara keseluruhan di BPRS Al Salaam masih dapat dikategorikan sehat seperti yang terlihat pada tabel 1.1 dimana NPF sebesar 4,17\% hal ini disebabkan karena pembiayaan di sektor konsumtif dengan skim jual beli atau akad murabahah cukup besar dengan kisaran $78 \%$ dari total seluruh pembiayaan yang disalurkan. Pembiayaan murabahah yang begitu dominan menjadikan pendapatan utama dari BPRS Al Salaam adalah margin atau laba dari skim akad jual beli. Beda halnya dengan pendapatan dari nisbah bagi hasil melalui pembiayaan mudharabah yang relatif lebih sedikit.

Pada tabel 1.2 dapat dilihat bahwa NPF akad mudharabah selama tahun 2016-2018 lebih besar dari batas ketentuan Bank Indonesia yaitu sebesar 5\%. Hal ini menunjukkan bahwa secara keuangan memiliki indikator yang tidak sehat. Dengan demikian, maka manajemen BPRS Al Salaam Cabang dituntut untuk melakukan upaya penurunan rasio NPF. Dari hasil wawancara kepada pihak BPRS diketahui bahwa BPRS Al Salaam Cabang Bandung sudah menetapkan beberapa kebijakan dalam mengatasi pembiayaan bermasalah diantaranya yaitu rescheduling (penjadwalan ulang), reiconditioning (persyaratan kembali) dan restructuring (penataan kembali), tetapi dalam kenyataannya jumlah kredit bermasalah dalam pembiayaan mudharabah tetap tinggi. Oleh karena itu, perlu diketahui apa yang menjadi fokus permasalahannya didalam faktor-faktor penyebab terjadinya pembiayaan mudharabah yang bermasalah baik dilihat dari aspek manajemen bank dan aspek nasabah di BPRS Al Salaam Cabang Bandung.

Berdasarkan uraian latar belakang masalah di atas, maka penulis tertarik untuk meneliti tentang faktor-faktor yang menentukan terjadinya pembiayaan bermasalah (NPF) pada pembiayaan mudharabah di BPRS Al Salaam Cabang Kota Bandung dengan menuangkannya ke dalam judul penelitian: "FAKTOR INTERNAL DAN EKSTERNAL YANG MENENTUKAN NON PERFORMING FINANCING (NPF) PADA PEMBIAYAAN MUDHARABAH (Studi pada BPRS Al-Salaam Amal Salman Cabang Bandung)".

\section{B. Landasan Teori}

Pembiayaan dalam perbankan syariah atau istilah teknisnya aktiva produktif, menurut ketentuan Bank Indonesia adalah penanaman dana Bank Syariah baik dalam rupiah maupun valuta asing dalam bentuk pembiayaan, piutang, qard, surat berharga syariah, penempatan, penyertaan modal, penyertaan modal sementara, komitmen dan kontinjensi pada rekening administratif serta sertifikat wadiah Bank Indonesia (Muhammad, 2014: 302).

Veithzal Rivai dan Arviyan Arifin menjelaskan (2010: 700), pembiayaan adalah 
penyediaan uang atau tagihan yang dapat dipersamakan dengan itu, berdasarkan persetujuan atau kesepakatan pinjam meminjam antara bank dan/atau lembaga keuangan lainnya dengan pihak lain yang mewajibkan pihak peminjam untuk melunasi utangnya setelah jangka waktu tertentu dengan imbalan bagi hasil.

Berdasarkan pengertian tersebut di atas, dapat disimpulkan bahwa pembiayaan adalah pemberian fasilitas penyediaan dana untuk mendukung investasi yang telah direncanakan berdasarkan kesepakatan antara bank dengan pihak lain yang mewajibkan pihak yang dibiayai untuk mengembalikan uang atau tagihan tersebut setelah jangka waktu tertentu dengan imbalan atau bagi hasil.

\section{Hasil Penelitian dan Pembahasan}

Faktor Internal dan Eksternal Yang Menentukan Non Perfroming Financing (NPF) Pada Pembiayaan

Berikut adalah penelitian mengenai Faktor Internal dan Eksternal Yang Menentukan Non Performing Financing (NPF) Pada Pembiayaan Mudharabah di BPRS Al Salaam Cabang Bandung yang dilakukan dengan penyebaran kuisioner kepada 10 responden yang dianalisis menggunakan skala likert. Setelah dilakukan wawancara kepada responden yang terdiri dari 5 nasabah dan 5 manajemen bank terkait faktor penentu Non performing financing (NPF) Pada Pembiayaan Mudharabah di BPRS Al Salaam Cabang Bandung yang meliputi Aspek Manajemen Bank dan Aspek Nasabah.

Tabel 3.1 Tanggapan Karyawan Bank pada Aspek Manajemen Bank mengenai faktor yang menentukan NPF

\begin{tabular}{|c|c|c|c|}
\hline No & Indikator & $\begin{array}{l}\text { Nilai } \\
\text { Skor }\end{array}$ & $\begin{array}{c}\text { Skala } \\
\text { Intepr } \\
\text { etasi }\end{array}$ \\
\hline 1 & $\begin{array}{l}\text { Kurangnya } \\
\text { pemahaman SDM }\end{array}$ & & \multirow{2}{*}{ TM } \\
\hline \multicolumn{2}{|r|}{ Skor / Total Skor } & 9 & \\
\hline 2 & $\begin{array}{l}\text { Pihak Bank Syariah } \\
\text { tidak melakukan } \\
\text { evaluasi yang baik }\end{array}$ & & \multirow[t]{2}{*}{$\mathrm{TM}$} \\
\hline \multicolumn{2}{|r|}{ Skor / Total Skor } & 11 & \\
\hline 3 & $\begin{array}{l}\text { Adanya kekeliruan } \\
\text { pihak Bank }\end{array}$ & & \multirow{2}{*}{$\mathrm{CM}$} \\
\hline \multicolumn{2}{|r|}{ Skor / Total Skor } & 13 & \\
\hline 4 & $\begin{array}{lr}\text { Bank } & \text { Syariah } \\
\text { melakukan } & \\
\text { perhitungan } & \text { modal } \\
\text { kerja } & \text { tidak } \\
\text { didasarkan } & \text { kepada } \\
\text { bisnis } & \text { usaha } \\
\text { nasabah } & \\
\end{array}$ & & \multirow[t]{2}{*}{$\mathrm{TM}$} \\
\hline \multicolumn{2}{|r|}{ Skor / Total Skor } & 11 & \\
\hline 5 & $\begin{array}{l}\text { Bank Syariah } \\
\text { melakukan analisa } \\
\text { pembiayaan } \\
\text { Nasabah dengan } \\
\text { asumsi yang terlalu } \\
\text { optimis }\end{array}$ & & \multirow[t]{2}{*}{ M } \\
\hline \multicolumn{2}{|r|}{ Skor / Total Skor } & 19 & \\
\hline 6 & $\begin{array}{lr}\text { Bank } & \text { Syariah } \\
\text { melakukan analisa } \\
\text { pembiayaan }\end{array}$ & & M \\
\hline
\end{tabular}




\begin{tabular}{|c|c|c|c|}
\hline No & Indikator & $\begin{array}{l}\text { Nilai } \\
\text { Skor }\end{array}$ & \multirow[t]{2}{*}{$\begin{array}{l}\text { Skala } \\
\text { Intepr } \\
\text { etasi }\end{array}$} \\
\hline \multicolumn{2}{|r|}{ Skor / Total Skor } & 19 & \\
\hline 7 & $\begin{array}{l}\text { Bank Syariah } \\
\text { menganalisis aspek } \\
\text { jaminan kurang } \\
\text { memperhitungkan } \\
\text { nilai pasarnya }\end{array}$ & & \multirow[t]{2}{*}{$\mathrm{CM}$} \\
\hline \multicolumn{2}{|r|}{ Skor / Total Skor } & 13 & \\
\hline 8 & $\begin{array}{l}\text { Lemahnya supervisi } \\
\text { dan monitoring }\end{array}$ & & \multirow[t]{2}{*}{ M } \\
\hline \multicolumn{2}{|r|}{ Skor / Total Skor } & 19 & \\
\hline 9 & $\begin{array}{l}\text { Adanya indikasi } \\
\text { KKN }\end{array}$ & & \multirow{2}{*}{ STM } \\
\hline \multicolumn{2}{|r|}{ Skor / Total Skor } & 7 & \\
\hline \multicolumn{2}{|r|}{ Rata-rata Skor } & 13.4 & CM \\
\hline
\end{tabular}

Sumber: Data olahan Penulis, 2019.

Berdasarkan tabel diatas, nilai rata-rata pada Aspek Manajemen Bank menurut tanggapan Karyawan Bank memperoleh rata-rata skor sebesar 13,4. Artinya, faktor-faktor yang meliputi: (1) Kurangnya pemahaman SDM terhadap bisnis yang dijalankan Nasabah, (2) Pihak Bank Syariah tidak melakukan evaluasi yang baik terhadap keuangan Nasabah tiap bulannya, (3) Adanya kekeliruan pihak Bank, (4) Bank Syariah melakukan perhitungan modal kerja tidak didasarkan kepada bisnis usaha nasabah, (5) Bank Syariah melakukan analisa pembiayaan Nasabah dengan asumsi yang terlalu optimis, (6) Bank Syariah melakukan analisa pembiayaan Nasabah tanpa memperhitungkan perilaku bisnis competitor nasabah, (7) Bank Syariah menganalisis aspek jaminan kurang memperhitungkan nilai pasarnya, (8) Lemahnya supervisi dan monitoring, (9) Adanya indikasi KKN. Indikator-indikator tersebut tergolong cukup menentukan NPF di BRPS Al-Salaam Cabang Bandung.

Tabel 3.2 Tanggapan Nasabah pada Aspek Manajemen Bank mengenai faktor yang menentukan NPF

\begin{tabular}{|c|c|c|c|}
\hline No & Indikator & $\begin{array}{l}\text { Nilai } \\
\text { Skor }\end{array}$ & $\begin{array}{c}\text { Skala } \\
\text { Intepretasi }\end{array}$ \\
\hline 1 & $\begin{array}{l}\text { Petugas Bank } \\
\text { tidak menanyakan } \\
\text { kondisi keuangan } \\
\text { setiap bulannya }\end{array}$ & & \multirow[t]{2}{*}{$\mathrm{CM}$} \\
\hline \multicolumn{2}{|c|}{ Skor / Total Skor } & 14 & \\
\hline 2 & $\begin{array}{l}\text { Petugas Bank } \\
\text { tidak pernah } \\
\text { melakukan } \\
\text { pengawasan atau } \\
\text { pendampingan } \\
\text { terhadap usaha } \\
\text { nasabah }\end{array}$ & & \multirow[t]{2}{*}{ M } \\
\hline \multicolumn{2}{|c|}{ Skor / Total Skor } & 21 & \\
\hline 3 & $\begin{array}{lr}\text { Setiap } & \text { ada } \\
\text { evaluasi } & \text { pihak } \\
\text { Bank } & \text { Syariah } \\
\text { tidak memberikan } \\
\text { saran dan masukan }\end{array}$ & & \multirow[t]{2}{*}{ M } \\
\hline \multicolumn{2}{|c|}{ Skor / Total Skor } & 18 & \\
\hline 4 & $\begin{array}{l}\text { Pihak bank tidak } \\
\text { terlalu meniliti } \\
\text { atau menggali } \\
\text { lebih lanjut atas } \\
\text { usaha nasabah } \\
\end{array}$ & & \multirow[t]{2}{*}{ M } \\
\hline \multicolumn{2}{|c|}{ Skor / Total Skor } & 19 & \\
\hline 5 & $\begin{array}{l}\text { Adanya } \\
\text { pemberian } \quad \text { uang }\end{array}$ & & TM \\
\hline
\end{tabular}




\begin{tabular}{|c|c|c|c|}
\hline \multirow{2}{*}{ No } & Indikator & $\begin{array}{c}\text { Nilai } \\
\text { Skor }\end{array}$ & $\begin{array}{c}\text { Skala } \\
\text { Intepretasi }\end{array}$ \\
\cline { 3 - 4 } & $\begin{array}{l}\text { tambahan sebagai } \\
\text { pelancar }\end{array}$ & \\
\hline \multicolumn{2}{|c|}{ Skor / Total Skor } & 9 & \\
\hline \multicolumn{2}{|c|}{ Rata-rata Skor } & $\mathbf{1 6 . 2}$ & CM \\
\hline
\end{tabular}

Sumber: Data olahan Penulis, 2019.

Berdasarkan tabel diatas, nilai rata-rata pada Aspek Manajemen Bank menurut tanggapan Nasabah memperoleh rata-rata skor sebesar 16,2. Artinya, faktor-faktor yang meliputi: (1) Petugas Bank tidak menanyakan kondisi keuangan setiap bulannya, (2) Petugas Bank tidak pernah melakukan pengawasan atau pendampingan, (3) Setiap ada evaluasi pihak Bank Syariah tidak memberikan saran dan masukan, (4) Pihak bank tidak terlalu meniliti atau menggali lebih lanjut atas usaha nasabah, (5) Adanya pemberian uang tambahan sebagai pelancar. Indikator-indikator tersebut tergolong cukup menentukan NPF di BRPS Al-Salaam Cabang Bandung.

Tabel 3.3 Tanggapan Karyawan Bank pada Aspek Nasabah mengenai faktor yang menentukan NPF

\begin{tabular}{|c|c|c|c|}
\hline No & Indikator & $\begin{array}{l}\text { Nilai } \\
\text { Skor }\end{array}$ & $\begin{array}{c}\text { Skala } \\
\text { Intepretasi }\end{array}$ \\
\hline 1 & $\begin{array}{l}\text { Karakter nasabah } \\
\text { yang tidak amanah } \\
\text { (tidak jujur dalam } \\
\text { memberikan } \\
\text { informasi dan } \\
\text { laporan tentang } \\
\text { kegiatannya }\end{array}$ & & \multirow[t]{2}{*}{ M } \\
\hline \multicolumn{2}{|c|}{ Skor / Total Skor } & 21 & \\
\hline 2 & $\begin{array}{lr}\text { Pihak Nasabah } \\
\text { melakukan side } \\
\text { streaming atau } \\
\text { menggelontorkan } \\
\text { kreditnya ke } \\
\text { keperluan lain } \\
\text { dalam penggunaan } \\
\text { dana pembiayaan }\end{array}$ & & \multirow[t]{2}{*}{ SM } \\
\hline \multicolumn{2}{|c|}{ Skor / Total Skor } & 22 & \\
\hline 3 & $\begin{array}{l}\text { Kemampuan } \\
\text { pengelolaan } \\
\text { nasabah tidak } \\
\text { memadai sehingga } \\
\text { kalah dalam } \\
\text { persaingan usaha }\end{array}$ & & \multirow[t]{2}{*}{ M } \\
\hline \multicolumn{2}{|c|}{ Skor / Total Skor } & 18 & \\
\hline 4 & $\begin{array}{lr}\text { Usaha } & \text { yang } \\
\text { dijalankan } & \\
\text { Nasabah } & \text { relatif } \\
\text { baru } & \\
\end{array}$ & & \multirow[t]{2}{*}{$\mathrm{CM}$} \\
\hline \multicolumn{2}{|c|}{ Skor / Total Skor } & 13 & \\
\hline 5 & $\begin{array}{lr}\text { Bidang usaha yang } \\
\text { telah } & \text { digeluti } \\
\text { Nasabah } & \text { telah } \\
\text { jenuh } & \\
\end{array}$ & & \multirow[t]{2}{*}{ M } \\
\hline \multicolumn{2}{|c|}{ Skor / Total Skor } & 19 & \\
\hline 6 & $\begin{array}{l}\text { Pihak Nasabah } \\
\text { tidak mampu } \\
\text { menanggulangi } \\
\text { masalah }\end{array}$ & & M \\
\hline
\end{tabular}




\begin{tabular}{|c|c|c|c|}
\hline No & Indikator & $\begin{array}{l}\text { Nilai } \\
\text { Skor }\end{array}$ & $\begin{array}{c}\text { Skala } \\
\text { Intepretasi }\end{array}$ \\
\hline \multicolumn{2}{|r|}{ Skor / Total Skor } & 19 & \\
\hline 7 & $\begin{array}{l}\text { Pihak Nasabah } \\
\text { yang telah } \\
\text { menerima } \\
\text { pembiayaan lebih } \\
\text { mementingkan } \\
\text { pemenuhan } \\
\text { konsumsi }\end{array}$ & & \multirow[t]{2}{*}{ M } \\
\hline \multicolumn{2}{|r|}{ Skor / Total Skor } & 19 & \\
\hline 8 & \begin{tabular}{|l|} 
Nasabah lebih \\
memprioritaskan \\
pembayaran \\
angsuran pada \\
lembaga lain \\
\end{tabular} & & \multirow[t]{2}{*}{ M } \\
\hline \multicolumn{2}{|r|}{ Skor / Total Skor } & 21 & \\
\hline 9 & $\begin{array}{lr}\text { Sering } & \text { terjadinya } \\
\text { kondisi } & \text { Force } \\
\text { Majeur } & \\
\end{array}$ & & \multirow{3}{*}{ M } \\
\hline \multicolumn{2}{|r|}{ Skor/Total Skor } & 18 & \\
\hline \multicolumn{2}{|r|}{ Rata-rata Skor } & 18.9 & \\
\hline & $\mathbf{z}$ & & \\
\hline
\end{tabular}

Berdasarkan tabel diatas, nilai rata-rata pada Aspek Nasabah menurut tanggapan Karyawan Bank memperoleh rata-rata skor sebesar 18,9. Artinya, faktor-faktor yang meliputi: (1) Karakter nasabah yang tidak amanah, (2) Pihak Nasabah melakukan side streaming, (3) Kemampuan pengelolaan nasabah tidak memadai, (4) Usaha yang dijalankan Nasabah relatif baru, (5) Bidang usaha yang telah digeluti Nasabah telah jenuh, (6) Pihak Nasabah tidak mampu menanggulangi masalah, (7) Pihak Nasabah yang telah menerima pembiayaan lebih mementingkan pemenuhan konsumsi, (8) Nasabah lebih memprioritaskan pembayaran angsuran pada lembaga lain, (9) Sering terjadinya kondisi Force Majeur. Indikator-indikator tersebut menentukan NPF di BRPS Al-Salaam Cabang Bandung.

Tabel 3.4 Tanggapan Nasabah pada Aspek Nasabah mengenai faktor yang menentukan NPF

\begin{tabular}{|c|c|c|c|}
\hline No & Indikator & $\begin{array}{l}\text { Nilai } \\
\text { Skor }\end{array}$ & $\begin{array}{c}\text { Skala } \\
\text { Intepretasi }\end{array}$ \\
\hline 1 & $\begin{array}{l}\text { Nasabah tidak } \\
\text { memberikan } \\
\text { informasi dan } \\
\text { laporan keuangan } \\
\text { tentang kegiatan } \\
\text { usahanya }\end{array}$ & & $\mathrm{CM}$ \\
\hline \multicolumn{2}{|r|}{ Skor / Total Skor } & 17 & \\
\hline 2 & $\begin{array}{l}\text { Nasabah tidak } \\
\text { membelanjakan } \\
\text { dana pembiayaan } \\
\text { yang sesuai dengan } \\
\text { pengajuan awal } \\
\text { kepada pihak bank }\end{array}$ & & \multirow[t]{2}{*}{$\mathrm{CM}$} \\
\hline & Skor / Total Skor & 13 & \\
\hline 3 & $\begin{array}{l}\text { Nasabah merasa } \\
\text { tidak memiliki } \\
\text { kemampuan }\end{array}$ & & M \\
\hline
\end{tabular}




\begin{tabular}{|c|c|c|c|}
\hline \multirow[t]{2}{*}{ No } & Indikator & $\begin{array}{l}\text { Nilai } \\
\text { Skor }\end{array}$ & $\begin{array}{c}\text { Skala } \\
\text { Intepretasi }\end{array}$ \\
\hline & $\begin{array}{l}\text { pengelolaan usaha } \\
\text { yang memadai }\end{array}$ & & \\
\hline \multicolumn{2}{|r|}{ Skor / Total Skor } & 18 & \\
\hline 4 & $\begin{array}{l}\text { Usaha yang } \\
\text { dijalankan nasabah } \\
\text { relatif baru }\end{array}$ & & \multirow[t]{2}{*}{$\mathrm{CM}$} \\
\hline \multicolumn{2}{|r|}{ Skor / Total Skor } & 16 & \\
\hline 5 & $\begin{array}{l}\text { Kegiatan usaha yang } \\
\text { nasabah jalankan } \\
\text { mengalami } \\
\text { kejenuhan dan tidak } \\
\text { mengalami } \\
\text { peningkatan }\end{array}$ & & \multirow[t]{2}{*}{ M } \\
\hline \multicolumn{2}{|r|}{ Skor / Total Skor } & 21 & \\
\hline 6 & $\begin{array}{l}\text { Nasabah tidak } \\
\text { mampu } \\
\text { menanggulangi } \\
\text { masalah yang terjadi } \\
\text { kepada kegiatan } \\
\text { usaha yang sedang } \\
\text { Saya jalankan }\end{array}$ & & \multirow[t]{2}{*}{ M } \\
\hline \multicolumn{2}{|r|}{ Skor / Total Skor } & 21 & \\
\hline 7 & $\begin{array}{l}\text { Nasabah lebih } \\
\text { mementingkan } \\
\text { kebutuhan konsumsi } \\
\text { dibanding modal } \\
\text { usaha }\end{array}$ & & \multirow[t]{2}{*}{ M } \\
\hline \multicolumn{2}{|r|}{ Skor / Total Skor } & 18 & \\
\hline 8 & $\begin{array}{l}\text { Nasabah lebih } \\
\text { memprioritaskan } \\
\text { pembayaran } \\
\text { angsuran kepada } \\
\text { bank lain }\end{array}$ & & \multirow[t]{2}{*}{$\mathrm{CM}$} \\
\hline \multicolumn{2}{|r|}{ Skor / Total Skor } & 17 & \\
\hline 9 & $\begin{array}{l}\text { Nasabah mengalami } \\
\text { kegagalan dalam } \\
\text { menjalankan } \\
\text { usahanya }\end{array}$ & & \multirow[t]{2}{*}{ M } \\
\hline \multicolumn{2}{|r|}{ Skor / Total Skor } & 21 & \\
\hline 10 & $\begin{array}{l}\text { Munculnya pesaing } \\
\text { baru yang menjual } \\
\text { produk yang sama }\end{array}$ & & M \\
\hline & kor / Total Skor & 21 & \\
\hline & Rata-rata Skor & 18.3 & $\mathbf{M}$ \\
\hline
\end{tabular}

Berdasarkan tabel diatas, nilai rata-rata pada Aspek Nasabah menurut tanggapan nasabah memperoleh rata-rata skor sebesar 18,3. Artinya, faktor-faktor yang meliputi: (1) 
Nasabah tidak memberikan informasi dan laporan keuangannya, (2) Nasabah tidak membelanjakan dana pembiayaan yang sesuai, (3) Nasabah merasa tidak memiliki kemampuan pengelolaan usaha yang memadai, (4) Usaha yang dijalankan nasabah relatif baru, (5) Kegiatan usaha yang nasabah jalankan mengalami kejenuhan, (6) Nasabah tidak mampu menanggulangi masalah yang terjadi, (7) Nasabah lebih mementingkan kebutuhan konsumsi, (8) Nasabah lebih memprioritaskan pembayaran angsuran kepada bank lain, (9) Nasabah mengalami kegagalan dalam menjalankan usaha, (10) Munculnya pesaing baru. Indikator-indikator tersebut menentukan NPF di BRPS Al-Salaam Cabang Bandung.

\section{Kesimpulan}

Berdasarkan hasil pembahasan dan penelitian ini, penulis menarik kesimpulan sebagai berikut:

1. Faktor dari aspek manajemen bank menurut perspektif karyawan bank maupun nasabah berada pada interval cukup menentukan terjadinya pembiayaan bermasalah. Indikatornya yaitu, faktor Bank syariah melakukan analisa pembiayaan nasabah dengan asumsi yang terlalu optimis, faktor Bank syariah melakukan analisa pembiayaan nasabah tanpa memperhitungkan aspek kompetitor, faktor Lemahnya supervisi dan monitoring yang dilakukan bank syariah, faktor setiap ada evaluasi pihak bank tidak memberikan saran dan masukan dan faktor pihak bank tidak terlalu meneliti lebih lanjut atas usaha yang dijalankan nasabah.

2. Faktor dari aspek nasabah menurut perspektif karyawan bank maupun nasabah berada pada interval menentukan terjadinya pembiayaan bermasalah atau NPF. Indikatornya yaitu, faktor pihak nasabah melakukan side streaming, faktor karakter nasabah yang tidak amanah, faktor kemampuan pengelolaan nasabah tidak memadai, faktor bidang usaha yang digeluti nasabah telah jenuh, faktor pihak nasabah tidak mampu menanggulangi masalah, faktor pihak nasabah yang menerima pembiayaan lebih mementingkan pemenuhan konsumsi, faktor nasabah lebih memprioritaskan pembayaran angsuran pada lembaga lain, faktor sering terjadinya force majeur, faktor nasabah mengalami kegagalan dalam menjalankan usaha dan faktor munculnya pesaing baru.

3. Faktor yang paling dominan dari aspek manajemen bank yaitu faktor Lemahnya supervisi dan monitoring. Adapun faktor-faktor yang paling dominan dari aspek nasabah yaitu faktor bidang usaha yang digeluti nasabah telah jenuh, faktor pihak nasabah tidak mampu menanggulangi masalah, faktor pihak nasabah yang menerima pembiayaan lebih mementingkan pemenuhan konsumsi dan faktor kemampuan pengelolaan nasabah tidak memadai.

\section{E. Saran}

1. Manajemen BPRS Al Salaam hendaknya melakukan strategi lain dalam upaya penyelamatan pembiayaan bermasalah selain difokuskan untuk menyita jaminan pembiayaan. Dapat juga dilakukan dengan cara menerapkan kebijakan selektif dalam pemberian pembiayaan kepada nasabah. Salah satunya tindakan perbaikan pada faktor supervisi bank melalui suatu sistem yang efektif dalam maintenance nasabah sepatutnya dapat diterapkan secara optimal.

2. Nasabah hendaknya perbaiki performa dan kinerja, tingkatkan citra bisnis dan juga tingkatkan kreatifitas dan inovasi serta perlunya pengetahuan mengenai alokasi dana pembiayaan sehingga nasabah tidak menyalahgunakan dana yang telah diberikan oleh pihak bank untuk pemenuhan konsumsi dan juga perlunya mempelajari pengelolaan berwirausaha dengan cara dilakukannya pelatihan dan pendampingan yang diberikan pihak bank sebelum menjalankan usaha tersebut.

3. Bahwa Pemerintah melalui OJK sebagai regulator. Oleh karena itu, perlu ditingkatkan peningkatan pengawasan dan peningkatan standar kualifikasi karyawan BPRS khususnya dalam memitigasi manajemen resiko.

4. Untuk peneliti selanjutnya diteliti juga mengenai aturan-aturan yang membatasi 
kewenangan bank syariah dalam melakukan penyitaan agunan terkait pembiayaan bermasalah seperti aturan OJK maupun aturan Bank Indonesia yang mengatur tentang upaya-upaya penanganan pembiayaan bermasalah. Sehingga permasalahan terkait pembiayaan bermasalah dapat diantisipasi secara persuasif.

\section{Daftar Pustaka}

[1] Putra. (2018, September 26). Ini Dia 63 BPRS Peraih "Infobank Sharia Awards 2018". infobanknews.com: http://infobanknews.com/ini-dia-63-bprs-peraih-infobank-shariaawards-2018/

[2] Sutojo. (2007). Menangani Kredit Bermasalah (Konsep Dan Kasus) (Hlm. 2). Jakarta: Erlangga UI.

[3] Tiarani. (2018, Mei 14). Problematika Pembiayaan Bermasalah pada Perbankan Syariah dan Cara Mengatasinya. Kompasiana: https://www.kompasiana.com/ 